\title{
Women in the Religious and Publishing Worlds of Buddhist Master Miaokong (1826-188o)
}

\author{
Beata Grant
}

\section{Introduction}

Apart from images of (mostly elderly) women flocking to temples to light incense and mumble prayers, or loveless (and often lovely) young women consigned to the loneliness of the convent, the lives of religious women in premodern China remain largely clothed in scholarly obscurity. ${ }^{1} \mathrm{~A}$ big part of the problem is the nature of the primary sources dealing with religious women, which are either non-existent or so fragmentary and formulaically composed that they provide only glimpses into what the actual lives and experiences of these women may have been like. I believe, however, that such glimpses should not be dismissed out of hand, given that, when considered in context, they suggest a much greater engagement with larger religious trends than is often acknowledged. As an example of this, in this short essay I offer a preliminary exploration of the role of women in the energetic Buddhist revival that followed on the heels of the social turmoil and destructive violence of the Taiping Rebellion (1851-1864). ${ }^{2}$

Recent years have seen many excellent studies of what Raoul Birnbaum calls "one of the most remarkable periods of Chinese Buddhist history," during which a cohort of exceptionally dedicated figures devoted their lives to rebuilding monasteries and temples, as well as recovering and reprinting Buddhist texts that had been lost in the madness and mayhem of the rebellion. ${ }^{3}$ Not surprisingly, these studies focus primarily on well-known monks and laymen, such as Yang Wenhui 楊文會 (1837-1911), who in 1868 established the

1 This modest essay is dedicated to Albert Hoffstädt, who over the years has been unstinting and ever-generous in his friendship and support of my scholarly (and poetic) endeavors.

2 "The destruction wrought by the rebellion is almost unfathomable. Population estimates for the Lower Yangzi macroregion alone suggest that the population in 1843 had reached sixtyseven million, but that fifty years later in 1893 it had fallen to forty-five million." R. Keith Schoppa, The Columbia Guide to Modern Chinese History (New York: Columbia Univ. Press, 2000), 26.

3 Birnbaum, "Buddhist China at the Century's Turn," The China Quarterly 174 (2003): 431. 
influential Jinling Scriptural Press (Jinling kejing chu 金陵刻經處) in Nanjing, and is often referred to as the "father" of this Buddhist revival. ${ }^{4}$ Less wellknown but equally dedicated to publishing was Yang Wenhui's slightly older contemporary, the monk Miaokong 妙空 (1826-1880), also known as the Scripture-Printing Monk (Kejing seng 刻經僧). The five women highlighted in this essay were all lay followers and patrons of Miaokong. Their stories are found in a collection of informal anecdotes and accounts entitled Records of Things Heard and Seen Regarding the Cultivation of Rebirth in the Western Pure Land (Xiuxi wenjian lu 修西聞見錄), hereafter Records. ${ }^{5}$ This collection, which was started in 1864 and first printed in 1877, was compiled by Miaokong's father, Zheng Yingfang 鄭應房, who became a lay Buddhist later in life and adopted the religious name of Zhiguan 迟觀. Most of the accounts in this collection were written or recorded by Buddhist laymen in Miaokong's circle. Zheng Yingfang, however, was responsible for dividing them into seven general categories: monks, nuns, laymen, laywomen, virgins, miscellaneous anecdotes, and marvelous events. Three of the seven, in other words, are devoted to accounts of pious women, including the five women introduced in this essay, who were associated, directly or indirectly with Miaokong. Their stories, while inevitably constrained by the nature of the sources, suggest the ways in which laywomen both quietly sustained and actively contributed to the work of revival, both as models of lay practice and as patrons and donors.

\section{Miaokong: A Brief Biography}

Miaokong, whose secular name was Zheng Xuechuan 鄭學川, was born in Jiangdu 江都, Jiangsu province, to an upstanding scholarly family. ${ }^{6}$ His mother,

4 Holmes Welch, The Buddhist Revival in China (Cambridge, Mass.: Harvard Univ. Press, 1968), 3. For more on Yang Wenhui, see Gabriele Goldfuss, "Binding Sutras to Modernity: The Life and Times of Chinese Layman Yang Wenhui 1837-1911," Studies in Central and East Asian Religions 9 (1996): 54-74. See also Gregory Adam Scott, "Conversion by the Book: Buddhist Print Culture in Early Republican China” (Ph.D. diss., Columbia Univ., 2013).

5 СветA X78, no. $155^{2}$.

6 Most available scholarship on Miaokong is found in Chinese sources. See, for example, Xiong Runsheng 熊潤生, comp., Kejing seng Miaokong dashi zhuan 刻經僧妙空大師傳 (1910), reprinted in Guojia tushuguan fenguan 國家圖書館分館, Zhonghua Fojiao renwu zhuanji wenxian quanshu 中華佛教人物傳記文獻 全書 (Beijing: Xianzhuang shuju, 2008), 48:24308-24315. An online article I have also found useful is Wu Yuankai 武元康 "Manmu qingshan: Miaokong fashi he Jiangbei kejing chu” 滿目青山 9 妙空法師和江北刻經處 The Culture of Buddhism 1 (1999). <http://www.buddhism.com.cn/fjwh/1999o1/mmqs1999o1o2. htm $>$, last accessed December 10, 2019. 
Madame Tang 唐, was a devout Buddhist who appears to have exerted a considerable religious influence on her son. According to an anecdotal account in the Records, the young boy once asked her whether it was really true that not only must everyone die but that even Heaven and Earth would one day be destroyed. When she replied in the affirmative, he declared that he would devote his life to finding both a body and a place that would not perish. ${ }^{7}$ The same account also relates a more humorous side of the young Miaokong: once when he had done something wrong and his mother punished him, he asked her: "Are not you and I of the same essence? Why then are you punishing yourself?"8 She smiled and refrained from imposing any further punishment.

Miaokong's father, Zheng Yingfang, who as mentioned earlier, did not embrace Buddhism until later in life and largely due to his son's persuasive influence, was known for his scholarship as well as for his excellent cursive calligraphy and regulated verse. ${ }^{9}$ Toward the end of his life, he took up residence in an old Daoist hermitage in Yangzhou that his son had converted into a Buddhist retreat center called Jiyuan 雞園,, 10 which served as a place for devotees to gather for various rituals and Pure Land recitations, as well as a base for Miaokong when he was in the area. Zhang Yingfang would become one of his son's most active supporters. He would also make use of his scholarly acumen not only to compile the Records, but also two major ritual treatises and manuals on the Water and Land Great Feast (shuilu dazhai 水陸大齋). ${ }^{11}$

As a young man, Miaokong appeared to be destined for a distinguished official career, having passed the first-level (xiucai) civil-service degree with flying colors. However, after the sudden death of his mother-he was hiding from the Taiping rebels at the time and supposedly learned about her death from a dream in which she appeared to him-he began to delve more deeply into Buddhist texts such as the Kșitigarbha Sūtra (Dizang jing 地藏經). Then, as his personal grief became somewhat assuaged, he began to make friends with monastics and to devote himself almost entirely to the study of Buddhist

Zhu Zhuxian 朱竹咸,"Tang Ruren muzi yuanshu” 唐孺人母子緣述, свETA X78, no. 1552 , p. $406 \mathrm{a} 3-7$.

8 Ibid., p. 406a5-6.

9 See Hu Jingzhi 胡鏡之 “Zheng laoren biezhuan” 鄭老人別傳, CBETA X78, no.1552, p. 401b4-9.

10 Jiyuan or Cock's Park (Skt. Kukkuțāāma) was also the name of a major Indian Buddhist monastery built by King Aśoka.

$11 \quad$ Although he (I believe mistakenly) attributes them to Miaokong rather than Miaokong's father, both of these texts are listed and described (as massive and monumental) in Henrik H. Sorenson, "Textual Material Relating to Esoteric Buddhism outside the Taishō, Vols. 18-2," in Esoteric Buddhism and the Tantras in East Asia, ed. Charles D. Orzech et al. (Leiden: Brill, 2011), 51. 
scriptures. He also wrote prolifically on Buddhist topics, even before, in 1866 when he was forty-one years old, he actually took the tonsure. In 1859, a major collection of these works entitled the Pavilion Collection (Louge congshu 樓閣 㙍書) was prepared for printing by the Zongjing tang 宗鏡堂 in Hangzhou. It would be reprinted again in 1914, this time including texts written after he became a monk, as well as texts by some of his close associates, including his father. Many of these texts, especially those of a more didactic nature, appear to have acquired a fairly wide readership, among both men and women, in southeastern China.

At the time he decided to become ordained, Miaokong was engaged to a certain Ms. Hu 胡 (? -1895), his first wife having perished in the chaos of the Taiping rebellion. Ms. Hu, who took the religious name Shenkong 身空, never married, but instead took up residence in a small hermitage called the Haitian jingshe 海天精舍 in Jiangdu built by Miaokong for his stepmother, Mme. Wang 王. Like the Jiyuan, the Haitian jingshe would also become a refuge, in this case for Buddhist laywomen and nuns.

Even before taking ordination, Miaokong had dedicated himself to searching out and reprinting lost Buddhist texts. Once ordained, he established the Jiangbei Scripture-Printing Press in his hometown of Yangzhou, and then later other presses in cities such as Suzhou, 蘇州, Changshu 常熟, and Rugao 如臬. Through his writings, teachings, and publishing activities, Miaokong attracted a devoted following of supporters and sponsors among Buddhist laymen, many of purely regional reputation, and some more widely-known, such as the famous anti-Taiping general Wu Kunxiu 吴坤修 (1816-1872) who became a Buddhist devotee and dharma patron in his later years. ${ }^{12}$ However, as we shall soon see, there were also a number of laywomen who contributed significantly to Miaokong's efforts, although they have rarely received the attention that they deserve.

Before turning to these women, a few words regarding Miaokong's primary religious orientation might be useful. Like Yang Wenhui and many other Buddhists of his time, Miaokong's writings largely reflect a synthesis of Huayan thought and Pure Land practice. As Yang Wenhui put it, "In terms of teaching, I honor Xianshou (i.e., Fazang [643-712], the third patriarch and primary systematizer of the Huayan school); for practice I rely on Amitābha” (教宗賢首， 行在彌陀). ${ }^{13}$ Mention of the Amitābha Buddha and his Pure Land, and in

12 See Xu Zhi 余治 “Shu Wu ke Huayan helun hou” 書吳刻花嚴合論後, свETA X78, no, 1552, p. 400a7-11.

13 Liu Guijie (Liu Kuei-chieh) 劉貴傑, “Qingchu Huayan nianfo sixiang shixi: yi Shufa yu Peng Shaosheng wei lie” 清初華嚴念佛思想試析 : 以續法與彭紹升爲例 (On the Synthesis of Huayan Thought and Pure Land Practice by Early Qing Dynasty Buddhist 
particular, the practice and realization of nianfo samādhi 念佛三昧 can be found in all of the three versions of the Huayan Sütra: for example, in the famous "Entering the Dharmadhātu" chapter (入法界品) which relates the journey of the youth Sudhana (Shancai 善才) to fifty-three different teachers, we find several of these teachers offering the practice of nianfo as a useful method of achieving enlightenment. The Huayan monk Xufa 續法 (1641-1728) and later the famous Buddhist layman Peng Shaosheng 彭紹升 (religious name Jiqing 際清, 1740-179o) further argued that the practice of nianfo encompassed all of the other methods, and that all Buddhist teachings and practices eventually converged in the Pure Land. In advocating the practice of nianfo, however, both Xufa and Peng placed considerable emphasis on its "mind-only" aspectthat is, while they did not discount the notion of rebirth in the Pure Land after death, they believed that the Pure Land also existed within the mind and could be accessed in the here and now, for ultimately, to invoke the Amitābha Buddha was essentially to invoke the truth of own's own innately pure Buddhanature. Thus, we find Miaokong extensively commenting and teaching on the Huayan as well as the Amitäbha Sütra. Interested in reaching as wide an audience as possible, works such as his Forty-Eight Essential Points Regarding Buddha-Recitation (Nianfo sishi ba fa jieyao 念佛四十八法節要) laid out, with simplicity and concision, the method and benefits of nianfo practice. The following lines from this text, for example, explain the benefits of nianfo practice during periods of violence and social disruption such as the one caused by the Taiping.

I urge those plagued by anxieties to first settle their bodies and then straighten out their minds through the practice of nianfo. A religious offering may provide relief from momentary suffering, but to relieve the suffering of the successive kalpas, the practice of nianfo is essential. Whenever one sees man or beast in difficulty, but cannot save them by one's own strength, then one should hasten to practice nianfo on their behalf in order to bring peace to their souls. Or in the hours before dawn if one resolutely recites the name of the Buddha on behalf of the ghosts and spirits [of those who have died] in the widespread warfare and great suffering, one will be able melt away their resentments.

凡見苦惱者, 先安其身, 然後開導其心, 勸之念佛, 所謂救一時之 苦, 布施爲 急, 救歷劫之苦, 念佛爲要. 或見人物有難, 力不能救,

Scholars: With Xufa and Peng Shaosheng as Examples), Chung-Hwa Buddhist Journal 20 (2007): 242 . 
當急爲彼念佛, 安其魂識. 或清夜朗誦, 以施鬼神. 凡大兵大疫之年, 五更持誦佛名, 能消冤厲. 14

The ritual manuals for the Water and Land Great Feasts compiled by Miaokong's father also reflect this profound concern with placating the souls of the countless men and women who suffered violent deaths during the Taiping uprising.

\section{Miaokong's Female Dharma Patrons and Followers}

\section{Lady Xu}

According to Tang Chiping 唐持平, it was thanks to Miaokong's close friend and Dharma patron, the Buddhist layman Xu Lingxu 許靈虛, that the text mentioned above, Forty-Eight Essential Points Regarding Buddha, gained a wide circulation and contributed significantly to the revival of Pure Land practice in China's coastal area. ${ }^{15}$ However, Tang adds, the major force behind this surge of domestic devotion was actually $\mathrm{Xu}$ Lingxu's mother. Born into one wealthy and high-ranking family of scholar-officials and married into another, ${ }^{16}$ Lady Xu (徐太夫人) is described as being an ideal Confucian wife whose kindness extended not only to servants but also to the ill and the needy; Tang notes her readiness to come to the aid of anyone regardless of wealth or status. Tang Chiping also makes note of Lady Xu's great piety and remarks on the ripple effect her practice had on the other women in her extended family:

Her granddaughter Wuyuan was the first of these; she was followed by other young women, such as Yutong, Huaixi, Huanzhen, Yuanzhue, Yuxu, Yazou, Zhengjue (Xu Lingxu's concubine), and Wuzhen, each of them different in their accomplishments but all of them of shining spirit.

\section{孫女悟源其一也。若與同。若還西。若環真。若緣覺。若玉虛。 若雅奏。若正覺。若悟真。雖其中所造各殊。而精神畑炣。17}

\footnotetext{
$14<$ http://www.ucchusma.idv.tw/buddha/buddha1o.htm\#a16>. Accessed December 15, 2019.

15 Tang Chiping, "Xumu Xutaifuren biezhuan” 許母徐太夫人別傳, cвETA X78, no. 1552, p. 406c19-407a1.

16 Her father Xu Gongbao 徐宮保, held the position of tutor to the Crown Prince (taizi shaobao 太子少保); her husband Xu Yunian 許玉年 was also an official, but was especially known as a painter and philanthropist. 
The description of a wealthy elite laywoman's exemplary charity and devotion to nianfo practice is not unusual. In another Records account, this one by $\mathrm{Xu}$ Guozhen 徐國楨 (1870-1938), it was after reading Miaokong's Forty-Eight Essential Points Regarding Buddha that she took the religious name of Yinshen 印 深 and began to devote herself primarily to the practice of nianfo. He also notes that her influence extended beyond her family members. In fact, he claims that it was largely due to her example of dedicated practice during a time of crisis and turmoil that "the Pure Land dharma-gate was able to once again flourish in the Three Rivers and Huai-Hai regions” 故淨土法門, 復能盛行於三 江淮海間. ${ }^{18}$

\section{Madame Chen}

It was also after reading some of Miaokong's writings that Madame Chen 陳氏 from Rugao 如臮 became one of Miaokong's first disciples as well as one of his first patrons. Said to have been precociously intelligent as a girl, she married Lu Changling 盧長齡, with whom she had a companionate marriage and to whom she bore two sons. A highly educated woman, Madame Chen read widely in different literary genres, both poetry and prose, secular and religious. It appears to have been admiration for Miaokong's writing that led Madame Chen to seek spiritual guidance from Miaokong; she took formal refuge with him, and was given the religious name Benyi 本一. She was joined in her devotions by her husband, who was given the name Benyin 本音. Later, Madame Chen and her husband assisted Miaokong in setting up a branch of the original Jiangbei scriptural press in Rugao, about eighty-four miles away. For nearly a decade, she served as one of Miaokong's most active and generous lay supporters:

For ten years, she supported the printing of the scriptures as well as a wide range of meritorious rituals of releasing life and [the Grand Rites of] Water and Land. She also contributed 20,00o cash to the printing of a revised version of the Xiuxi wenjian lu. During the period of her illness, she would often say, "If I have [achieved any] spiritual realization, then may I never be separated from the Larger Perfection of Wisdom Sūtra."

\section{護刻經及水陸放生諸善事以十年. 助刻續補修西聞見錄者錢二萬中 云。我若有靈. 終不離大般若經也. 19}

Madame Chen and her husband were generous supporters of Miaokong's final and most ambitious project: a reprinting of the massive 6oo-fascicle Larger

18 Xu Guozhen, “Xu taifuren zhuan” 徐太夫人傳, с свETA X78, no. 1552, p. 406b21-22.

19 Mao Tongqing 冒同慶, “Shu Benyi shi” 書本一事, CBETA X78, no. 1552, p. 41ob21-23. 
Perfection of Wisdom Sūtra (Mahāprajñāpāramitā-sūtra 大般若波羅蜜經). ${ }^{20}$ Madame Chen, who had long suffered from ill health, passed away prematurely in her early forties. Before her death she wrote a letter to be delivered to Miaokong, in which she wrote:

Although I have long enjoyed [your] enlightening influence, I have yet to penetrate directly into the First Principle; I am ashamed [that by not doing so I have failed to show my gratitude] for the Master's great compassion. Nevertheless, I have yearned for the Great Vehicle, supported Buddhist activities, and tirelessly guided the younger generation [to the Pure Land practice]. Today, although I know that death awaits me, yet I am confident that my spirit will go to Jiyuan, where it will assist in the great work of printing and see the completion of the printing of the entire Buddhist canon.

受玉尺教澤甚久。於第一義未能直入。有愧師恩。然鄉往大乘。護持 佛事。接引後進。始終如一。今雖知死。然魂隗必赴雞園。 佐佑刊刻機緣。俟書全藏之成也. ${ }^{21}$

Madame Chen, however, was not Miaokong's first female supporter. That distinction goes to a woman by the name of Madame Jueluo 覺羅 (Gioro) who, with her husband, official, painter, and calligrapher Rushan Kuangjiu 如山冠 九 (jinshi 1838) became Miaokong's follower not long after his ordination in 1866..22 Madame Jueluo belonged to the Manchu ruling clan, and originally hailed from Changbai 長白 (today located on the border of Korea and China and now a Korean Autonomous County located in southern Jilin province). As in the case of Madame Chen, Madame Jueluo (whose religious name was Shanyi 善一) and her husband, who belonged to a Manchu bannerman clan, were both devout Buddhists. Once when the latter was in Hubei on business, he happened to get hold of Miaokong's Commentary on the Amitäbha Sūtra (Amituo jing zhujie 阿彌陀經注解). He was so taken with this text that he had it printed, after which he donated the printing blocks to the Guiyuan Monastery 歸元寺, a Caodong Chan monastery in Wuhan known for its collection of Buddhist texts and artifacts. He also brought a copy home, and it was through this text that Shanyi appears to have first became acquainted with Miaokong's writings. Shanyi's husband later met Miaokong while on an official business

\footnotetext{
$20 \quad$ Miaokong himself died three years before the entire work was printed in 1883 .

21 "Shu Benyi shi," светA X78, no. 1552, p. 410b3-6.

22 Zhao Dali 趙大禮, “Shu Shanyi shi” 書善一事, CBETA X78, no. 1552, p. 407b2-7.
} 
trip, and the monk subsequently made several visits to Shanyi and her husband at their home in Yangzhou. Each time he visited, Shanyi would ask him to give a dharma talk, and between visits he appears to have written him letters (unfortunately lost) with her questions. She would share Miaokong's replies to her letters not only with her husband, but also with other female friends and relatives, including her unmarried younger sister Jueluo Shengquan 覺羅聖全 who was still living in Changbai and who herself took up nianfo practice and considered Miaokong as her teacher, although she never met him in person. ${ }^{23}$

According to Jiang Yuanliang's account, in 1868, only two years after his ordination, Miaokong visited the couple in Quxian 眐縣, Zhejiang province, where Rushan Kuangjiu was serving as Salt Distribution Commissioner $(d u-$ zhuan 都轉). His visit coincided with the anniversary of the premature death of Madame Jueluo's younger sister back in Changbai, and she asked him to conduct a special ritual for her. She also asked him to give a dharma talk on the “Ten Mysterious Gates" (十玄門 shi xuanmen) of the Huayan Sütra. The talk was attended by many residents of Quxian, monastic and lay alike, and we are told that they all left both impressed and inspired by this monk who, while not young, had been ordained only very recently. Not long after this, Madame Jueluo also made a generous donation to help Miaokong in his printing ventures; in fact, she can be regarded as the first of his lay donors. Her reputation for dedicated devotion spread widely and served as motivation to many other women (and probably men as well) who were inspired by her example to take up the practice of nianfo.

\section{Ms. Peng Dingshen and Ms. Zhang Yunying}

The piety of these educated women represented a continuation of the religious lives of women a few decades earlier, such as those of the family of the eighteenth-century layman Peng Shaosheng. The most well-known of these women was Peng's daughter-in-law Tao Shan 陶善 ( $z i$ Qionglou 瓊樓), who was known for her deep devotion and who died in her early twenties shortly after having given birth to her first child. Highly educated, Tao Shan left a collection of poetry, much of it religious in nature, that was highly regarded by many and eventually included in later editions of the supplemental Buddhist canon. ${ }^{24}$ Sun Lingbo 孫靈波, the author of a short account included in the Records, notes that the female members of Peng Shaosheng's family, including not only

23 Jiang Yuanliang 蔣元亮, “Ji Shengquan shiji” 記聖全事蹟, CBETA X78, no. 1552, p. 414C410.

24 See Beata Grant, "Who is this I? Who is that Other? The Poetry of an Eighteenth-Century Buddhist Laywoman," Late Imperial China 15.11(1994): 1-40. 
Tao Shan but also his wife and two daughters, together constituted "a lineage of fragrant radiance" (yimai zhi xiangguang 一脈之香光). ${ }^{25}$ Sun goes on to remark that although the years of turmoil and warfare resulted in so many books and collections being scattered and lost, it was largely the succeeding generations of women of the family, including his great-granddaughter Peng Dingsheng 彭定生, who had managed to keep Peng Shaosheng's spirit alive. Miaokong, in his search for books to reprint, visited the family and was both moved and impressed by the women's dedication to the preservation and circulation of Peng Shaosheng's work, as well as the practice of the Pure Land devotion he so strongly advocated. ${ }^{26}$

The Zhang 張 family of Changshu 常熟 were also credited with having maintained the "spirit of the Pengs of Changzhou" (有長洲彭氏風), and again it appears to be the women of this family who were the ones primarily responsible for doing so. ${ }^{27}$ Of particular note was one of this family's daughters, Zhang Yunying 張曇影, who appears to have first met the elderly Miaokong when she was only thirteen sui, at which time she immediately asked him if she could take refuge with him. Miaokong, impressed with both her intelligence and her devotion, agreed and gave her the religious name Baofang 寶芳, urging her to study the Buddhist scriptures. At the age of sixteen sui, Wu tells us, Yunying gave up eating meat, and recited the name of the Buddha 10,000 times daily. However, she suffered from ill health (which may have been one of the precipitating reasons for her early piety), and just a few years later found herself at death's door. She passed away in the winter of 1883 , three years after Miaokong himself, with the name of Amitābha on her lips. Wu's account does not, however, stop here. It goes on to describe the manner in which Yunying, following Miaokong's instructions, applied herself to the study of the Buddhist scriptures:

The Woman of the Way [Yunying] was by nature quiet and gentle and spoke only rarely. Unless she was doing embroidery or her meditations, she was never without a book in her hand. Together with her two elder brothers she would discuss all of the esoteric scriptures, often deep into the night. She would study such scriptures as the Huayan Sütra, the Lotus Sütra, and the Sütra of Perfect Enlightenment, and was able to comprehend their meaning. She also carefully studied the Ten Essentials of the

\footnotetext{
25 Sun Lingbo, “Peng Dingsheng liming shuo" 彭定生立名說, свEтA X78, no. 1552, p. $407 \mathrm{~b} 18$.

26 Ibid., p. 407b2o-c2.

27 Wu Baocong 吳寶叢, “Yunying daoren zhuan” 曇影道人傳 CBETA X78, no. 1552, p. 417c21-24.
} 
Pure Land $;{ }^{28}$ moreover, she had an understanding of the teachings of the Tiantai and Xianshou [Huayan] schools of Buddhist teaching.

道人性溫靜。寊語言。不事女工。禪課之餘。手不釋卷。從兩兄討論 內典。輙至夜分。讀華嚴法華圓覺諸經能解其義。又精研淨土十要。 於台賢圓旨頗有會心 ${ }^{29}$

Finally, we are told — in typical rebirth account fashion — that toward the end, she was rewarded with a dream vision of the Bodhisattva Guanyin and was able to assure her family that she would be reborn in the Pure Land. However, we are also told that before her death, she left instructions that all of her money was to be used, presumably by Miaokong's press, to print five fascicles of The Great Commentary to the Huayan Sūtra (Huayan dachao 華嚴大鈔) for the edification of others. ${ }^{30}$

What we see here, then, is yet another example of a woman who combined Pure Land piety and a deep intellectual engagement with Buddhist texts. Interestingly, a one-fascicle collection of Yunying's own religious verse was later appended to the edition of the Huayan commentary that was printed owing to her donation. Although I have been unable to locate this collection, if indeed it is still extant, fortunately Wu thought to append to his account a series of her four verses under the title of "Cherishing the Pure Land (Huai Jingtu 懷淨土). ${ }^{31}$ The first of these verses reads as follows:

Carefully contemplating the Pure Land, a realm that is transparently clear;

Where the Buddha sun is eternally alight, a city that knows no darkness.

The birds' chatter, the flowers' fragrance: together they preach the Dharma;

Having cleansed our minds, we quietly listen and awaken to the Deathless.

諦觀安養境澄清, 佛日常開不夜城. 鳥語花香齊說法, 洗心寂㯖悟無生. 32

28 By Ouyi Zhixu 蕅益智旭 1599-1655), an eminent late-Ming monk who, although trained in Chan, was also a strong advocate of Pure Land practice. His Ten Essentials of the Pure Land (Jingtu shiyao 淨土十要) was a standard text of Pure Land practitioners.

29 CветA X78, no. 1552, p. 418a4-7.

30 I am not sure which of the several major commentaries on this sūtra is referred to here.

31 This was a popular type of religious verse-many late imperial monks and laymen also wrote series of poems under the same title, sometimes comprising as many as a hundred verses.

СветA $\mathrm{X}_{78}$, no. 1552 , p. 418a16-17. 


\section{Concluding Remarks}

The cases discussed briefly in this essay represent only a handful of the many (mostly) laywomen described in the accounts written by Miaokong's friends and associates and compiled by Miaokong's father. What is particularly noteworthy is the fact that while in many cases it was their pious devotional practice that garnered the highest praise, in many others acknowledgment was made of their dedicated study and mastery of Buddhist texts and, of course, their generous financial support of the work of recovering and reprinting texts that had been lost in the turmoil of the Taiping Rebellion. While the contributions of these women may not appear to compare with the achievements of the more well-known and charismatic male leaders of the Buddhist revival, including Miaokong himself, I would suggest that there may have been many more that have gone unrecorded or have been lost. In any case, the scattered cases that we do have can still, like pointillistic brushstrokes on a canvas when regarded as a whole, offer us a far more nuanced landscape of Chinese religious history during this tumultuous time. 